\title{
COPPER-BEARING TOURMALINES FROM NeW Deposits in Paraíba State, Brazil
}

\author{
Masashi Furuya
}

Two new deposits of Cu-bearing tourmaline have been found in Paraíba State, Brazil, not far from the original source at Mina da Batalha. The Glorious mine has produced a limited amount of gem-quality material with a composition that is similar to the tourmaline from Mina da Batalha. Initial work at the second locality, known as Mineração Batalha, has not yet produced any gem-quality material.

n 2006, new finds of copper-bearing elbaite tourmaline were made at two locations in Paraíba State, near the town of Junco do Seridó. This small town is located approximately $18 \mathrm{~km}$ northeast of Mina da Batalha, the site of the original discovery of the now world-famous "electric-blue Paraíba" Cu-bearing tourmalines (e.g., Fritsch et al., 1990). One of the new deposits, known as the Glorious mine, has produced gem-quality Paraíba tourmaline with some colors that resemble those found at Mina da Batalha (figure 1). The other locality-the Mineração Batalha mine-has not been worked as extensively but shows potential to produce gem-quality material in the future. This report provides a preliminary description of these new tourmaline deposits.

Glorious Mine. Location. The Glorious mine is located approximately $2 \mathrm{~km}$ west of Junco do Seridó at the following coordinates: longitude $36^{\circ} 43^{\prime} 59^{\prime \prime} \mathrm{W}$ and latitude $7^{\circ} 00^{\prime} 18^{\prime \prime}$. This new deposit falls within a zone of gem pegmatite dikes that extends from Mina da Batalha northward into neighboring Rio Grande do Norte State, where there are two similar gem-tourmaline deposits at the Alto dos Quintos (also known as Wild) and Mulungu (Terra

See end of article for About the Authors and Acknowledgments.

Gems \& Gemology, Vol. 43, No. 3, pp. 236-239.

(c) 2007 Gemological Institute of America
Branca) mines near Parelhas (Shigley et al., 2001; see figure 2 ). Over the years, pegmatites in the area have been mined intermittently on a small scale as sources of high-quality white kaolinite clay that is used for ceramics, with tourmaline often recovered as a byproduct.

Geology and Mining. The first report on the mining of Cu-bearing tourmaline from the Glorious deposit was published by Furuya and Furuya (2007). The nearly vertical pegmatite dike ranges from $20 \mathrm{~cm}$ to $2 \mathrm{~m}$ wide, and is partly kaolinitized. It is hosted by quartzite of the Equador Formation (again, see Shigley et al., 2001), and consists of feldspar (partially altered to kaolinite), quartz (sometimes smoky or amethyst), mica (dark reddish violet), and lesser amounts of black and colored tourmaline. The gem tourmaline is found as crystals and fragments embedded in kaolinite or in partially decomposed pegmatite. The tourmaline colors include blue, green-blue, green, and violet, with the most valuable blue material representing about $20 \%$ of the production. The violet material turns blue on heating, but the green material does not change significantly with heat treatment (H. Sakamaki, pers. comm., 2007). In some cases, the crystals are color zoned from the center outward, with a pink core, a bright blue zone, and a very dark green (almost black) exterior.

Like most gem mining in Brazil, recovery of tourmaline at the Glorious mine involves a small-scale operation. A Japanese company-Glorious Gems Co. Ltd., under the ownership of H. Sakamaki-operates the mine with a license from the Brazilian government. Approximately 25 employees work full-time at the mine; they use heavy machinery to remove as much as 20 tonnes of pegmatite material each day. Preliminary mining activities began in March 2006, with full operation three months later following the construction of a washing plant. The pegmatite is accessed by two shafts (and associated trenches), located about $100 \mathrm{~m}$ apart; as of March 2007, they had been excavated to a depth of $30 \mathrm{~m}$ (e.g., figure 3). The west shaft was 4 $\mathrm{m}$ wide, and the east shaft was $2 \mathrm{~m}$ wide. At the bottom of each shaft, tunnels extended sideways along the pegmatite.

The tourmaline is found both in cavities and "frozen" within quartz or kaolinitized feldspar. The pegmatite material is usually so decomposed that it can easily be broken 

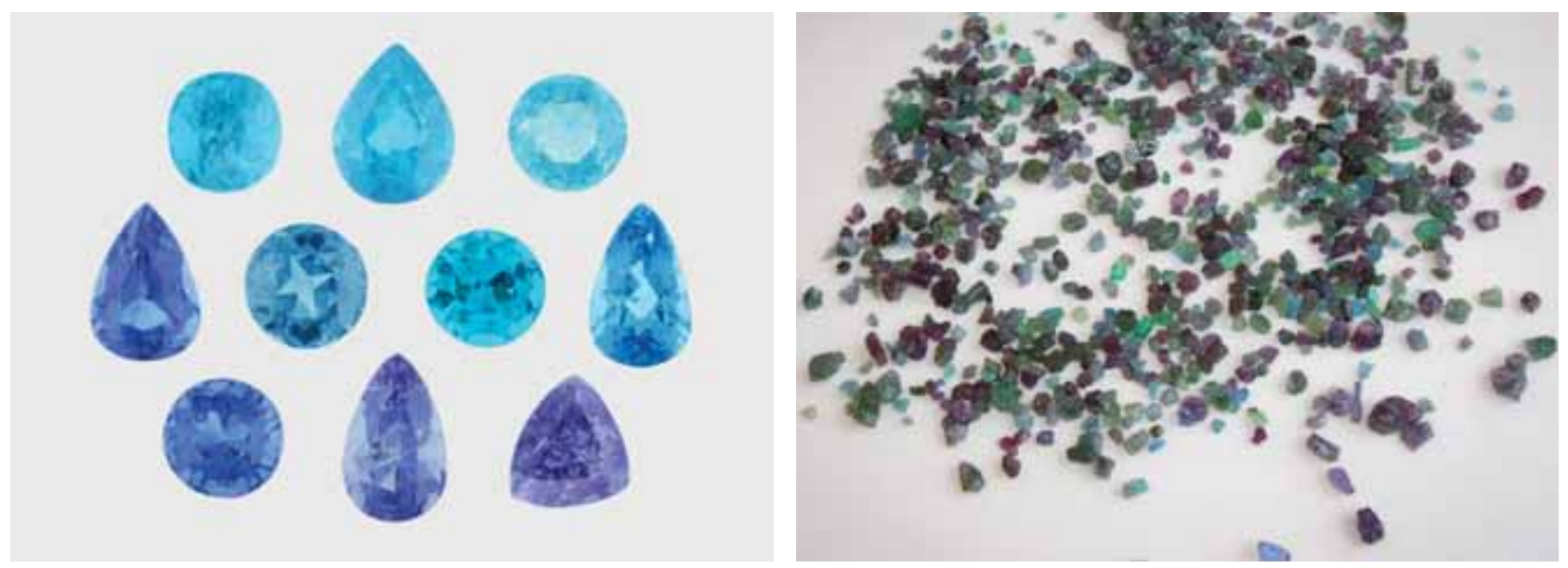

Figure 1. These unheated Cu-bearing tourmalines are from the new Glorious mine in Paraíba State, Brazil. The faceted stones weigh $0.15-0.34 \mathrm{ct}$, and the rough material ranges from 2 to $5 \mathrm{~mm}$. Most of the Glorious mine production is green and violet, and the balance contains various shades of blue. The violet material heat treats to blue. Photos by T. Komuro (left) and M. Furuya (right).

up with hand tools in the mine and then hauled to the surface in buckets. On occasion, the miners use a pneumatic drill to break up the pegmatite. All material removed from the dike is washed and hand-picked to recover the tourmaline. The largest tourmaline crystal (6.0 g, but with many cracks) was found at a depth of 10 $\mathrm{m}$ in December 2006. Many smaller pieces were found at $\sim 30 \mathrm{~m}$ depth. The largest clean crystal recovered thus far measured $3 \times 3 \times 12 \mathrm{~mm}$.
The total production to date of unheated blue tourmaline is approximately $500 \mathrm{~g}$, with only about 200 pieces of sufficient size and quality to be faceted $(\sim 40$ carats estimated after cutting). So far about 100 pieces of blue to greenish blue to violet tourmaline have been cut, each weighing around $0.20 \mathrm{ct}$.

Materials, Methods, and Results. Ten faceted stones $(0.15-0.34 \mathrm{ct})$ and 15 pieces of rough tourmaline $(0.08-0.60$

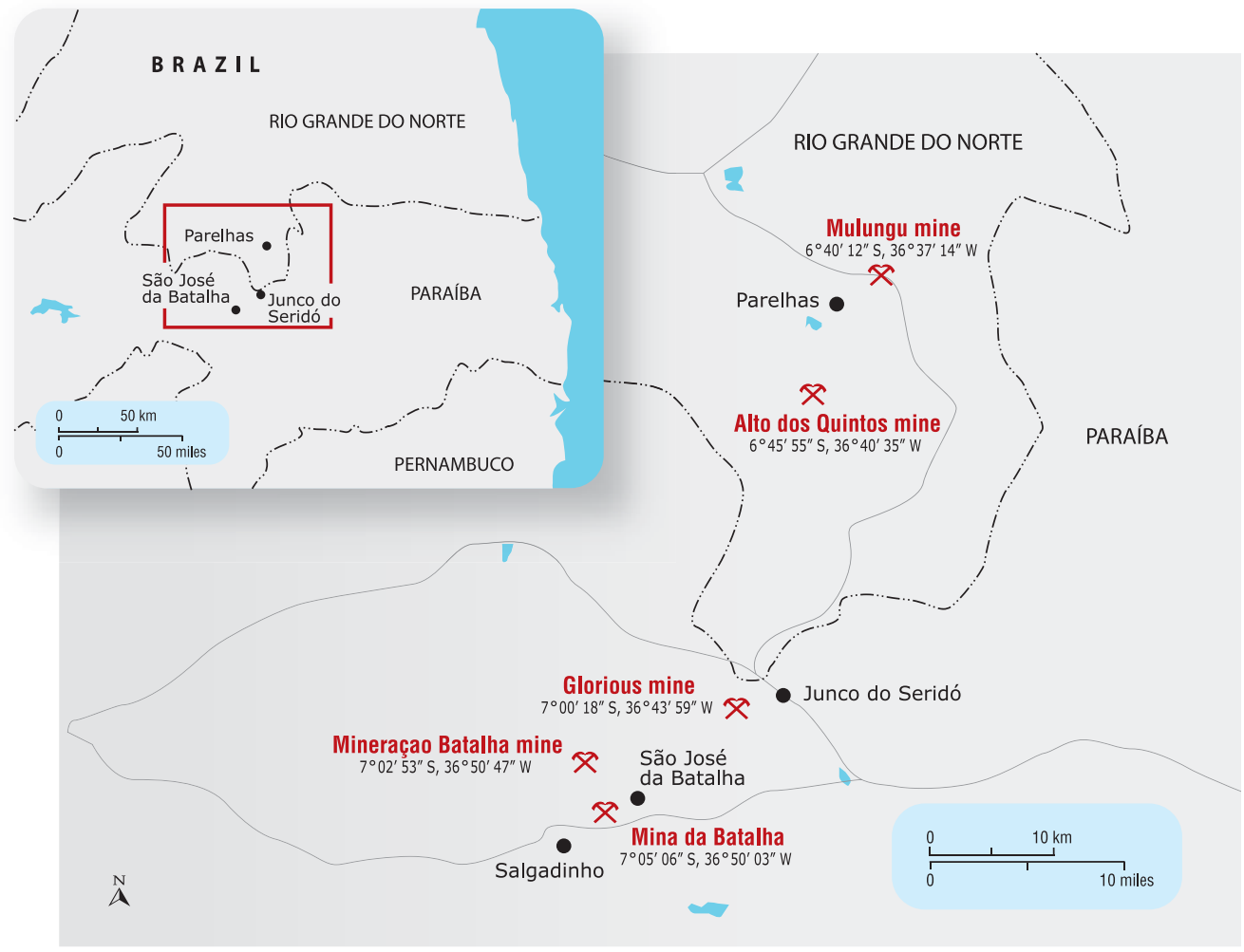

Figure 2. The new Glorious and Mineração Batalha mines are located in Paraíba State, close to the original Mina da Batalha deposit. 


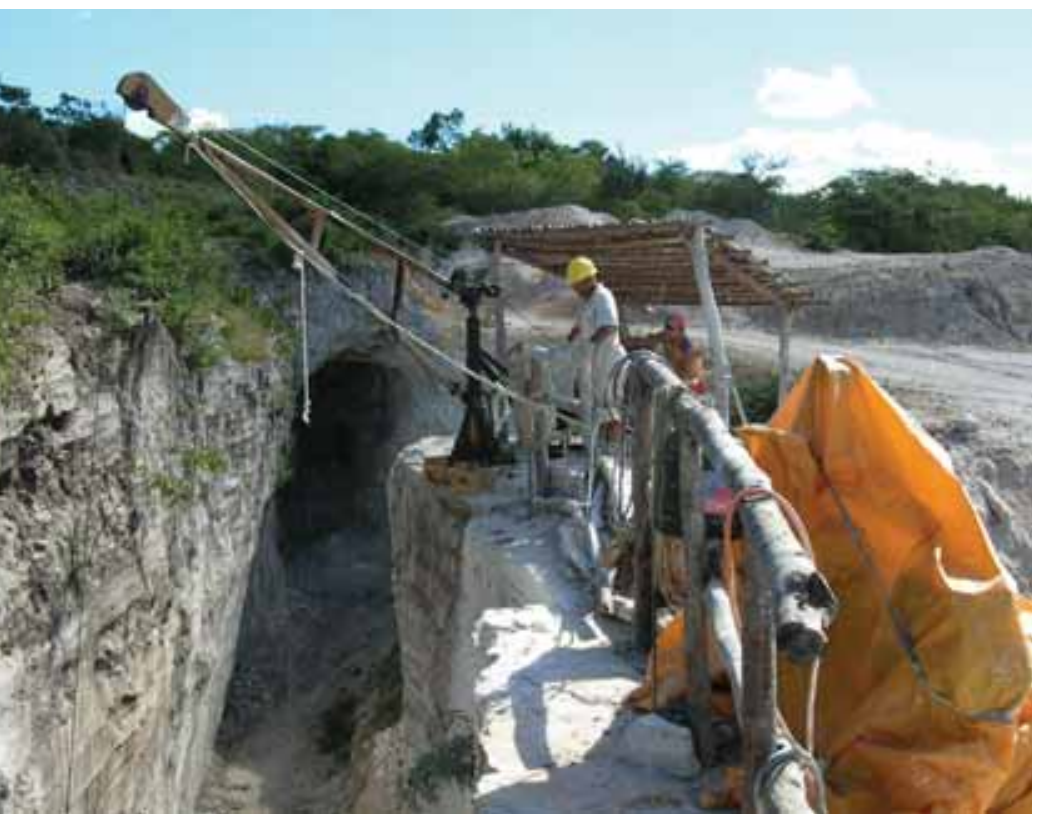

Figure 3. Excavation of the west shaft at the Glorious mine began in March 2006. As of March 2007, the trench and associated tunnels in this area reached $a$ depth of $30 \mathrm{~m}$. Photo by M. Furuya.

ct, average $0.30 \mathrm{ct}$ ) from the Glorious mine were studied for this report. The rough samples ranged from blue to green, and also included pink, violet, and brown, but only

Figure 4. Located just $4 \mathrm{~km}$ from the original Mina da Batalha deposit, the Mineração Batalha mine was being explored by a shaft $20 \mathrm{~m}$ deep in April 2007.

Photo by M. Furuya.

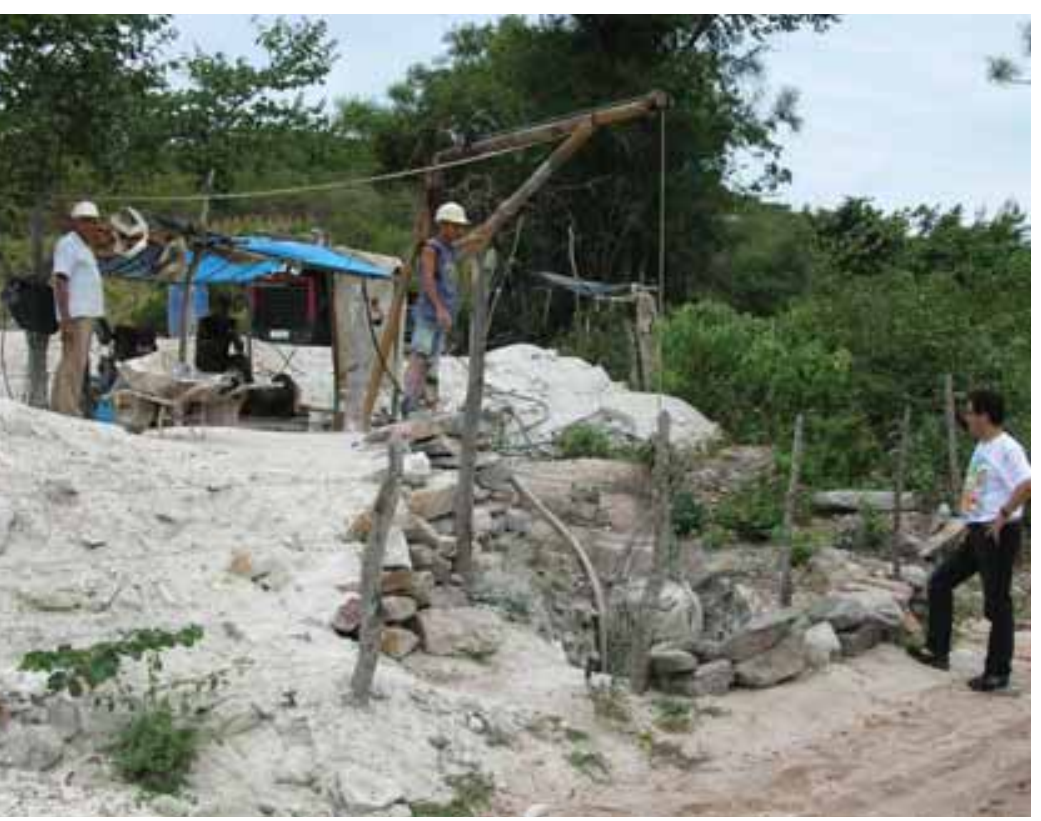

the chemical data for the blue-to-green rough samples are reported below. Gemological properties of the faceted tourmalines were as follows: color-greenish blue to blue to violet; $\mathrm{RI}-\mathrm{n}_{\mathrm{o}}=1.638-1.640$ and $\mathrm{n}_{\mathrm{e}}=1.618-1.620$; birefringence-0.018-0.021; SG-3.06-3.10; and fluorescenceinert to both long- and short-wave ultraviolet radiation. As is typical with other gem tourmalines, the Glorious samples contained two-phase (liquid and gas) inclusions and fluid-filled trichites. These inclusions resemble those seen in Paraíba tourmaline from Mina da Batalha.

Semiquantitative chemical data for all the samples were obtained by energy-dispersive X-ray fluorescence (EDXRF) spectroscopy. In addition, samples from other known deposits of Cu-bearing tourmaline were analyzed by the same instrument, for comparison (table 1); the colors included blue, "neon" blue, greenish blue to bluish green, and green. The Glorious mine tourmalines had an elbaite composition, and most samples had $\mathrm{Cu}>\mathrm{Mn}$, as in other Brazilian Paraíba-type tourmalines. The faceted Glorious mine samples contained more $\mathrm{Cu}$ than the tourmalines that were analyzed from the other localities.

Mineração Batalha Mine. This deposit (figure 4) is located a short distance from the Glorious mine (about 10 minutes by vehicle), and only $4 \mathrm{~km}$ north of Mina da Batalha. It was first recognized by A. Campos in October 2006. Two months later, Mr. Sakamaki invested in this deposit, which is currently operated by companies run by both men. A

Figure 5. At this underground exposure (20 $\mathrm{m}$ depth), the Mineração Batalha pegmatite is up to $30 \mathrm{~cm}$ wide. It is surrounded by very hard quartzite of the Equador Formation. Photo by M. Furuya.

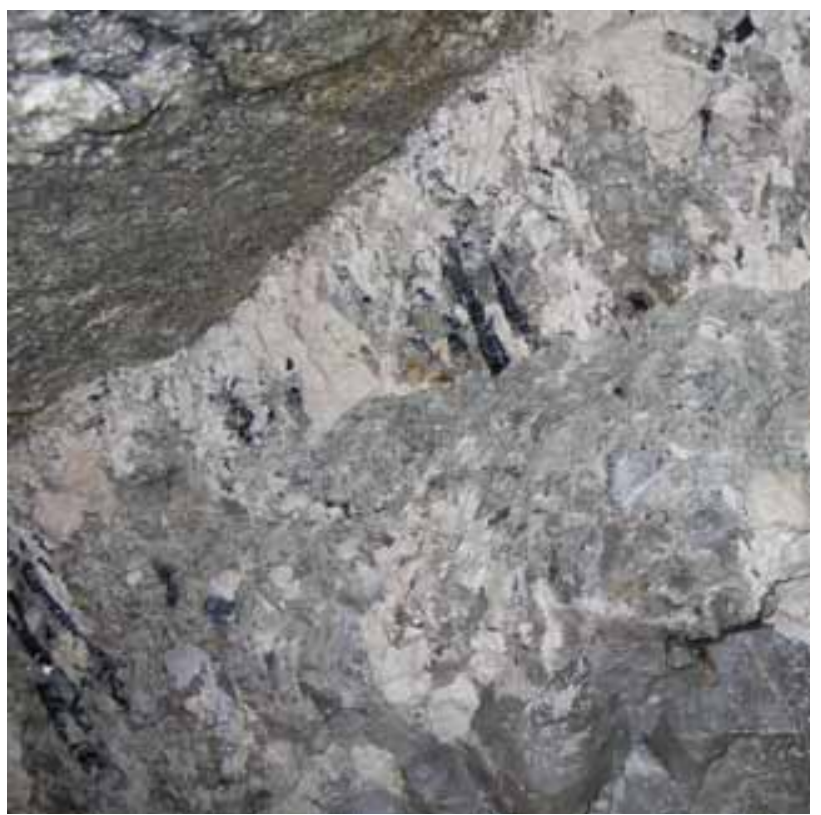


TABLE 1. Average semiquantitative chemical composition of some minor and trace elements (wt. \% oxide) in blue-to-green Cu-bearing tourmaline from the Glorious, Mineração Batalha, and six other mining areas. ${ }^{2}$

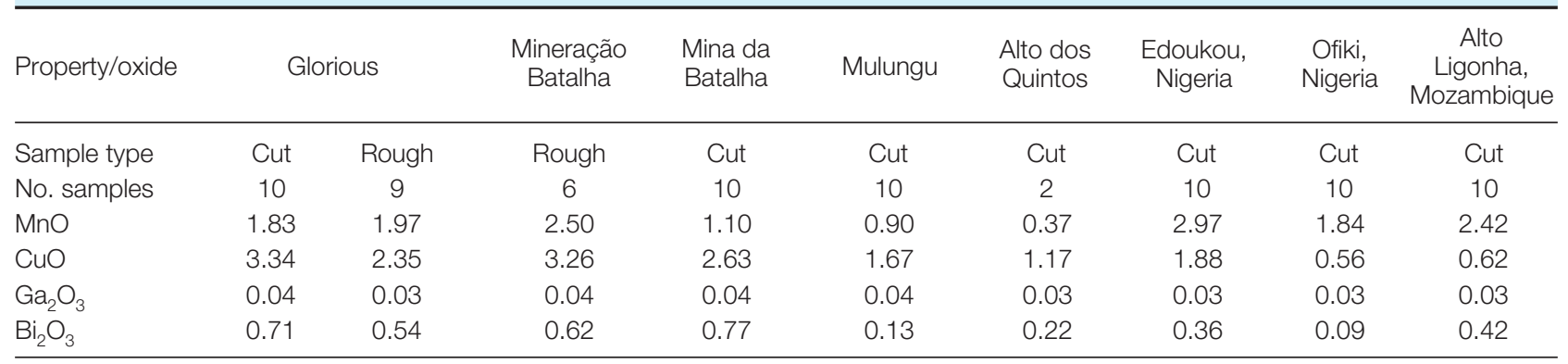

a Data collected by EDXRF using an Edax Eagle $\mu$ Probe, operated by K. Danjo, using $30 \mathrm{kV}$ voltage, 1,000 mA current, and a $100 \mu \mathrm{m}$ spot size.

Chemical data were calculated assuming 1.62 wt. \% $\mathrm{Li}_{2} \mathrm{O}, 10.94$ wt. $\% \mathrm{~B}_{2} \mathrm{O}_{3}$, and 3.13 wt. \% $\mathrm{H}_{2} \mathrm{O}$, as reported for Cu-bearing elbaite by Fritsch et al. (1990).

decomposed (partially kaolinitized) pegmatite dike that is 20-70 cm wide (figure 5) is being explored by a single shaft that was about $20 \mathrm{~m}$ deep in April 2007. Mining began in early 2007, with a crew of 15 workers using hand tools and a pneumatic drill. Dynamite is sometimes needed because the host quartzite is much harder here than at the Glorious mine. Miners typically remove about 5 tonnes of pegmatite material each day for washing and sorting by hand.

The copper-bearing tourmaline at Mineração Batalha is found within kaolinitized feldspar, in areas that are rich in black tourmaline, rubellite, and smoky quartz. Many of the crystals are bicolored, with a beautiful blue outer layer and a pink-to-violet core (figure 6). The larger crystals can attain weights up to $5 \mathrm{~g}$, but the material recovered to date contains numerous inclusions and is too fragile for cutting; no stones had been cut at the time of this writing.

Figure 6. Tourmaline from the Mineração Batalha mine is commonly color zoned, with an "electric" blue rim and a pink-to-violet interior. Photo by M. Furuya.

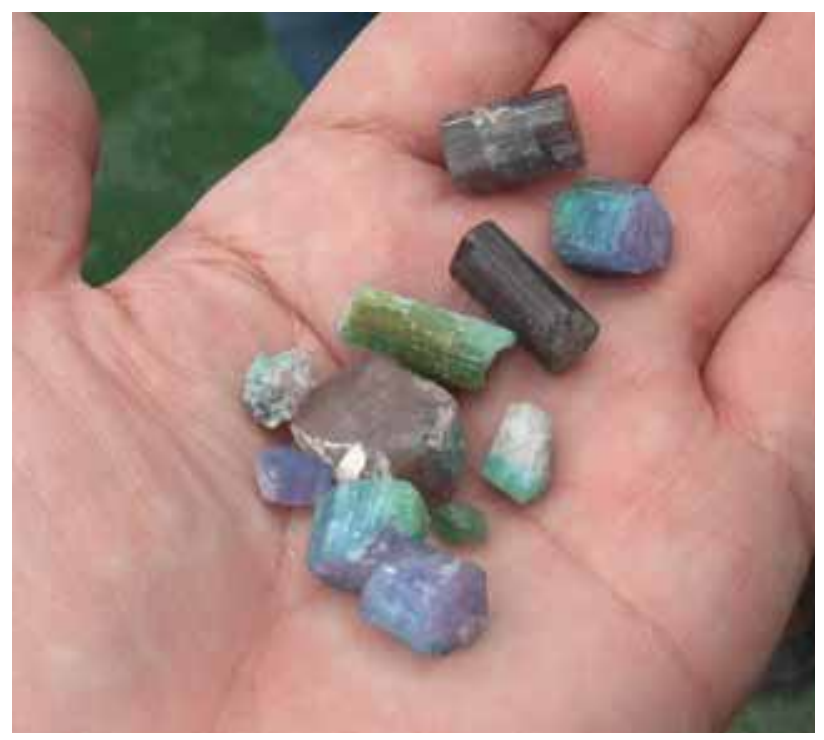

EDXRF analyses of six small blue crystals of Mineração Batalha tourmaline (again, see table 1) revealed contents of $\mathrm{Cu}$ and $\mathrm{Mn}$ similar to those for blue tourmaline from Mina da Batalha. Given the close proximity of this new mine to Mina da Batalha, the owners are optimistic that it will produce good material in the future.

Conclusion. In 2006, mining began at two new Cu-bearing tourmaline deposits in Brazil's Paraíba State: the Glorious and Mineração Batalha mines. The ongoing discovery of Cu-bearing tourmaline in this region indicates that its numerous pegmatites have not been fully explored for gem material. The bright blue coloration shown by some of the tourmalines from these two new occurrences is comparable to that of the copper-bearing tourmalines first discovered almost 20 years ago at Mina da Batalha. Given the high value of this material on the gem market, any new supply of such tourmalines is significant.

\section{ABOUT THE AUTHOR}

Mr. Furuya (jgg/@sapphire.co.jp) is director of the Japan Germany Gemmological Laboratory in Kofu, Japan.

\section{ACKNOWLEDGMENTS}

The author is grateful to Mr. Hideki Sakamaki (Glorious Gems Co. Ltd., Tokyo) and Mr. Artaxerxes Campos (Mineração Batalha Ltda., Recife, Brazil) for providing the opportunity to visit the Glorious and Mineração Batalha mines, and for supplying many of the samples for this report.

\section{REFERENCES}

Furuya M., Furuya M. (2007) Paraíba Tourmaline-Electric Blue Brilliance Burnt into Our Minds. Japan Germany Gemmological Laboratory, Kofu, Japan, 24 pp.

Fritsch E., Shigley J.E., Rossman G.R., Mercer M.E., Muhlmeister S.M., Moon M. (1990) Gem-quality cuprian-elbaite tourmalines from São José da Batalha, Paraíba, Brazil. Gems ↔) Gemology, Vol. 26, No. 3, pp. 189-205.

Shigley J.E., Cook B.C., Laurs B.M., de Oliveira Bernardes M. (2001) An update on "Paraíba" tourmaline from Brazil. Gems «) Gemology, Vol. 37, No. 4, pp. 260-276. 